\title{
Penyuluhan Tentang Pengembangan Literasi Baca Dan Numerasi Melalui Media Pop Up Box di Sekolah Dasar Se-Kecamatan Praya Lombok Tengah
}

\author{
Ida Bagus Kade Gunayasa1, Moh. Irawan Zain², Ketut Sri Kusuma Wardani*, Fitri Puji Astria ${ }^{4}$ \\ 1,2,3,4Program Studi Pendidikan Guru Sekolah Dasar, FKIP, Universitas Mataram \\ *e-mail: srikusumawardani@unram.ac.id ${ }^{3}$
}

\begin{abstract}
In this era of modernization, the growth of reading and numeracy literacy is expected and required. Nevertheless, significant training is required to use pop-up box media to promote reading and numeracy literacy in a novel way. This community service activity takes the form of counseling and training, which can be divided into two categories: public lectures and guided exercises. Preparation, supplying tools and materials, implementation, and assessment are the processes that will be carried out in this activity in detail. Based on the outcomes of the activities, the implementation of this counseling activity proceeded successfully, and the activities were completed according to the timetable. Preparation, provision of tools and resources, implementation, and evaluation all went off without a hitch. The community service team supplied a response questionnaire relating to the activity's implementation to gauge the success of the activity, with the results of the activity's execution being excellent.
\end{abstract}

Keywords: counseling, development of reading literacy, numeracy, pop-up box

\begin{abstract}
Abstrak
Pengembangan literasi baca dan numerasi sangat diharapkan dan dibutuhkan di era moderenisasi ini. Namun untuk melakukan pengembangan literasi baca dan numerasi ini secara inovatif melalui media pop up box dibutuhkan latihan yang intensif. Kegiatan pengabdian masyarakat ini berbentuk penyuluhan dan pelatihan, yang dapat dikelompokan ke dalam dua bentuk kegiatan, yaitu ceramah umum dan pemberian latihan terbimbing. Adapun tahapan secara detail yang akan dilaksanakan pada kegiatan ini yaitu persiapan, menyediakan alat dan bahan, pelaksanaan dan evaluasi. Berdasarkan hasil kegiatan yang telah dilaksanakan, pelaksanaan kegiatan penyuluhan ini berjalan dengan lancar dan jadwal pelaksanaan kegiatan sesuai dengan agenda yang telah direncanakan. Rangkaian kegiatan mulai dari persiapan, menyediakan alat dan bahan, pelaksanaan dan evaluasi berjalan dengan lancar. Untuk mengukur keberhasilan kegiatan, tim pengabdian kepada masyarakat memberikan angket respon terkait pelaksanaan kegiatan dengan hasil pelaksanaan kegiatan sudah terlaksana dengan sangat baik.
\end{abstract}

Kata kunci: penyuluhan, pengembangan literasi baca, numerasi, pop-up box

\section{PENDAHULUAN}

Dewasa ini persoalan dalam dunia pendidikan kian marak terjadi dan mengkhawatirkan. Utamanya terkait isu-isu tentang literasi, numerasi, dan juga minat baca di Indonesia yang semakin mengkhawatirkan. Para pakar yang bergelut di bidang pendidikan dan semua pihak yang memiliki atensi terhadap pemunculan berbagai kasus tersebut termasuk pemerintah, tidak hentihentinya melakukan upaya mengidentifikasi faktor-faktor penyebab, upaya preventif (pencegahan), dan menawarkan sejumlah upaya penanganan yang kiranya dapat digunakan sebagai formula yang berguna dan bermanfaat. Salah satu upaya nyata yang dilakukan ialah merevisi dan memperbaharui muatan kurikulum yang berlaku di setiap jenjang pendidikan. Meskipun harus disadari, bahwa persoalan demi persoalan yang terjadi dan mewarnai dunia pendidikan tidak semata-mata dipicu oleh ketidaksempurnaan desain kurikulum yang berlaku di negara ini.

Berbicara mengenai budaya literasi atau budaya membaca, masyarakat Indonesia pada umumnya memiliki budaya literasi yang dapat dikatakan rendah/kurang jika dibandingkan dengan budaya literasi masyarakat di negara-negara lain. Masyarakat Indonesia cenderung dan lebih senang berbicara daripada membaca atau dengan kata lain, budaya berbicara lebih dominan daripada budaya membaca dan numerasi. Hal ini didukung beberapa data sebagai berikut: United Nations Educational, Scientific, and Cultural Organization (UNESCO) tahun 2011 melansir hasil 
surveinya yang menunjukkan indeks tingkat membaca masyarakat Indonesia hanya 0,001 persen, atau hanya ada satu orang dari 1000 penduduk yang mau membaca buku. Data Perpustakaan Nasional tahun 2017, frekuensi membaca orang Indonesia rata-rata hanya tiga sampai empat kali per minggu. Sementara jumlah buku yang dibaca rata-rata hanya lima hingga sembilan buku per tahun. Hasil dari berbagai survei tersebut menunjukkan bahwa literasi merupakan masalah yang serius dalam dunia pendidikan di Indonesia.

Berdasarkan hasil wawancara dari beberapa guru-guru SD di Kab. Lombok Tengah pada Awan Januari 2021 dapat diketahui bahwa guru tidak menyadari pentingnya mengembangkan literasi baca dan numerasi dalam melaksanakan pembelajaran di sekolah inklusif, mereka hanya memanfaatkan bahan ajar yang telah tersedia dalam buku pelajaran, namun belum pernah mengeksplorasi pengalaman siswa secara inovatif dan menggunakan media pop up box serta pembelajaran terkesan monotun dan membosankan. Sebagian besar dari mereka mengalami kebingungan bagaimana harus mengembangkan pengalaman siswa dalam upaya pengembangan literasi baca dan numerasi yang lebih variatif dan menyenangkan, bagaimana memulainya dan bagaimana melakukannya. Pertanyaan- pertanyaan ini muncul kemungkinan besar disebabkan oleh keterbatasan pengetahuan dan pengalaman serta informasi yang diperoleh juga sangat terbatas, terutama terhadap pemahaman tentang hakikat literasi baca dan numerasi. Padahal pengembangan literasi baca dan numerasi sangat diharapkan dan dibutuhkan di era moderenisasi ini. Namun untuk melakukan pengembangan literasi baca dan numerasi ini secara inovatif melalui media pop up box dibutuhkan latihan yang intensif.

Bertolak pada fakta tersebut, gerakan literasi baca dan numerasi kini kian gencar dan giat dilakukan. Budaya literasi baca dan numerasi pada akhirnya akan menciptakan masyarakat yang literat. Gerakan dan literasi ini sekiranya akan mengurangi dan mengubah secara perlahan paradigma dan budaya masyarakat yang lebih dominan dan senang berbicara menjadi terbiasa, cinta, serta menjadikan literasi baca dan numerasi sebagai kebutuhan dan kebiasaan/budaya.

Budaya dan gerakan literasi baca dan numerasi tidak hanya menyasar kepada masyarakat secara umum. Gerakan ini secara khusus diintensifkan pelaksanaannya pada jalur pendidikan formal (sekolah) melalui Gerakan Literasi Seklah (GLS) yang diimplementasikan melalui media pop up box. Dalam praktiknya, gerakan ini membutuhkan keterlibatan, dukungan, dan kerja sama semua pihak di sekolah-sekolah inklusif serta penerapan model dan metode pembelajaran yang tepat untuk merealisasikan gerakan literasi baca dan numerasi melalui media pop up box.

Untuk menyelesaikan permasalahan yang dihadapi guru sekolah mitra, maka dilakukan kegiatan penyuluhan tentang pengembangan literasi baca dan numerasi melalui media pop up box di SD se-kecamatan Praya Lombok Tengah. Dengan adanya kegiatan tersebut, diharapkan agar guru-guru dapat meningkatkan kreativitas, memberikan pengetahuan secara lebih mendalam tentang pengembangan literasi baca dan numerasi melalui media pop up box dan mengimplementasikannya dalam pembelajaran inklusif pada guru-guru SD di Kecamatan Praya Lombok Tengah, serta memotivasi guru-guru SD di Kecamatan Praya Lombok Tengah agar dapat meningkatkan profesionalismenya dengan berkreativitas melalui kegiatan melakukan pengembangan literasi baca dan numerasi melalui media pop up box.

\section{METODE}

Kegiatan pengabdian masyarakat ini berbentuk penyuluhan dan pelatihan, yang dapat dikelompokan ke dalam dua bentuk kegiatan, yaitu ceramah umum dan pemberian latihan terbimbing. Masing-masing tahapan kegiatan, tim pengabdian akan mendampingi guru dari awal kegiatan sampai selesai kegiatan. Adapun tahapan secara detail yang akan dilaksanakan pada kegiatan Pengabdian kepada Masyarakat terkait dengan penyuluhan tentang pengembangan literasi baca dan numerasi melalui media pop up box di Sekolah Dasar Se-Kecamatan Praya Lombok Tengah adalah sebagai berikut: 


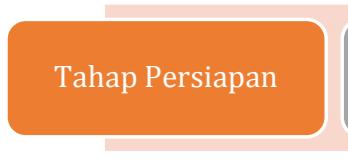
Tahap Menyediakan
Alat dan Bahan
Tahap Pelaksanaan

\section{Gambar 1. Diagram alur pelaksanaan kegiatan}

\subsection{Tahap Persiapan}

Persiapan penyuluhan dilakukan melalui dua kegiatan yaitu kegiatan survey lapangan dan rapat koordinasi kegiatan dengan tim pengabdian. Kegiatan survey dilakukan dengan melakukan wawancara kepada guru-guru di Sekolah Dasar Kecamatan Praya Lombok Tengah untuk menggali informasi terkait masalah-masalah yang mungkin dapat diselesaikan oleh tim pengabdian.
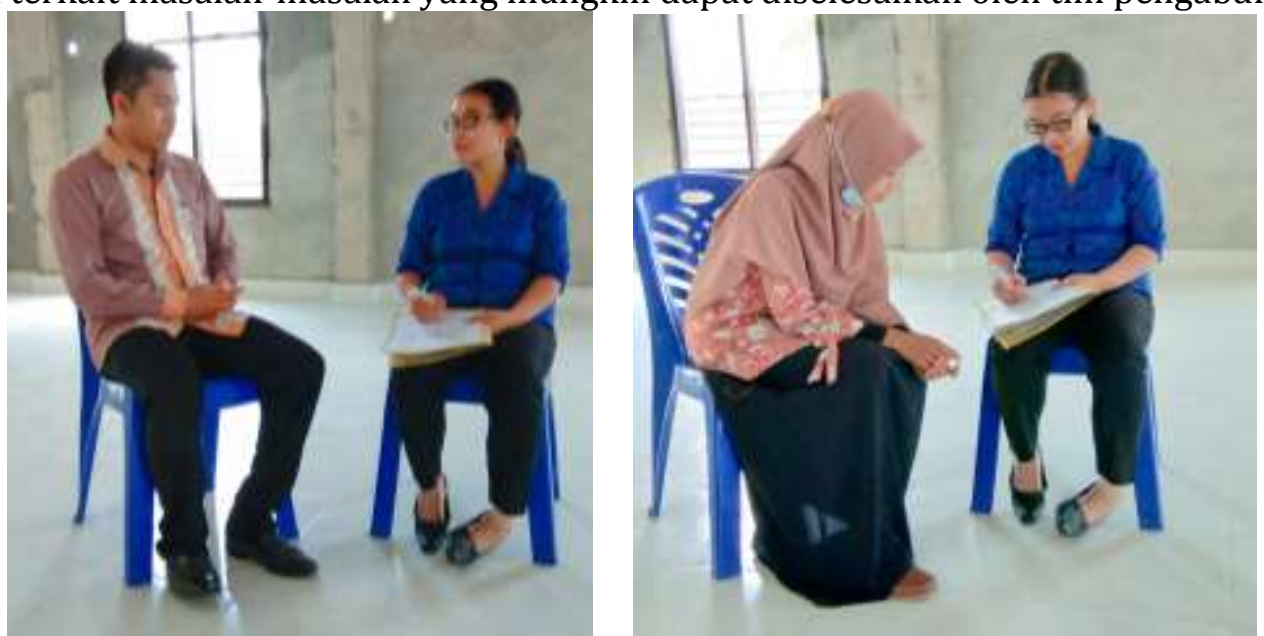

Gambar 2. Dokumentasi Survey Lapangan oleh Tim Pengabdian

\subsection{Tahap Menyediakan Alat dan Bahan}

Tahapan kegiatan selanjutnya adalah menyiapkan alat dan bahan. Tim pengabdian berusaha menyiapkan media pop up box yang sudah jadi, sebagai contoh untuk Bapak/Ibu guru di Sekolah Dasar Se-Kecamatan Praya Lombok Tengah. Media ini juga digunakan sebagai alat untuk mendemonstrasikan penggunaan media pop up box untuk pengembangan literasi baca dan numerasi.
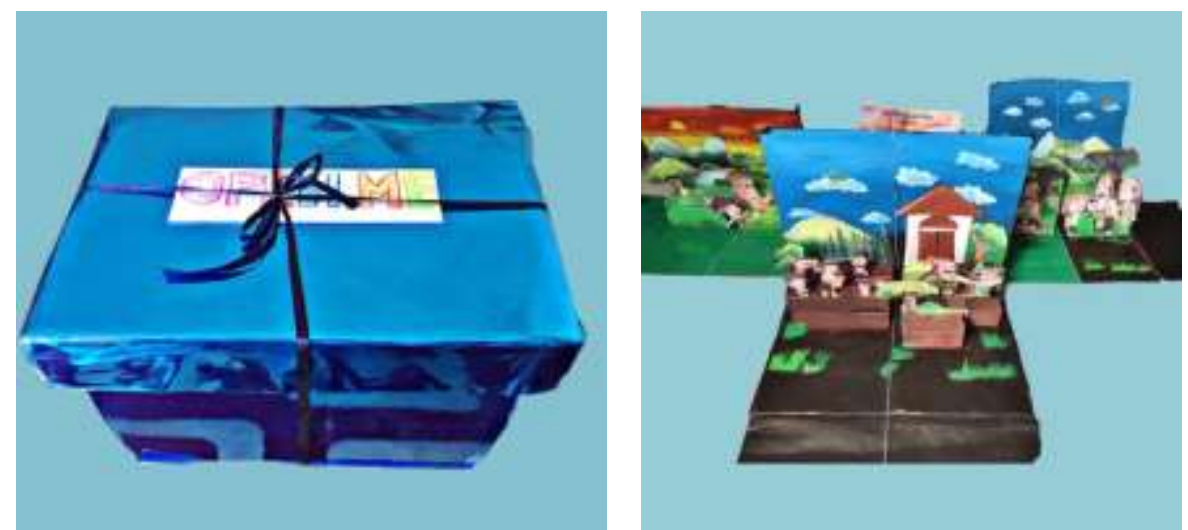

Gambar 3. Media Pop Up Box

\subsection{Tahap Pelaksanaan}

Tahap pelaksanaan kegiatan penyuluhan tentang pengembangan literasi baca dan numerasi melalui media pop up box dilaksanakan pada hari Sabtu, 23 Oktober 2021. Adapun 
materi yang disajikan dalam penyuluhan adalah: 1) Pandangan umum mengenai fenomena budaya literasi dalam dunia Pendidikan di Sekolah oleh Dr. Ida Bagus Kade Gunayasa, M.Hum., 2) Prinsip-prinsip pengembangan literasi baca dan numerasi di Sekolah oleh Ketut Sri Kusuma Wardani, S.Pd., M.Pd. 3) Strategi pengembangan literasi baca dan numerasi di Sekolah oleh Moh.Irawan Zain, S.Pd., M.Pd. 4) Pengembangan Media Pop Up Box dan Praktik Penggunaan Media Pop Up Box oleh Fitri Puji Astria, M.Pd dan Baiq Wini Audia Damayanti. Kegiatan dimulai pukul 09.00 Wita dengan susunan acara pada tabel 1 berikut.

Tabel 1. Rundown Acara Penyuluhan tentang Pengembangan Literasi Baca dan Numerasi melalui Media Pop Up Box di Sekolah Dasar Se-Kecamatan Praya Lombok Tengah

\begin{tabular}{|c|l|l|l|}
\hline No & $\begin{array}{c}\text { Waktu } \\
\text { (WITA) }\end{array}$ & \multicolumn{1}{|c|}{ Kegiatan } & $\begin{array}{l}\text { Penanggungjawab/ } \\
\text { Pembicara }\end{array}$ \\
\hline 1 & $09.00-09.30$ & Registrasi Peserta & Panitia \\
\hline 2 & $09.30-09.40$ & Pembukaan & $\begin{array}{l}\text { MC (Fitri Puji Astria, } \\
\text { M.Pd) }\end{array}$ \\
\hline 3 & $09.40-09.50$ & Sambutan Ketua Tim Pengabdian & $\begin{array}{l}\text { Dr. Ida Bagus Kade } \\
\text { Gunayasa, M.Hum }\end{array}$ \\
\cline { 3 - 5 } & & Sambutan Ketua PGRI Kab. Lombok Tengah & H. Amir, S.Pd \\
\hline 4 & $09.50-10.00$ & Doa & Optional \\
\hline 5 & $10.00-10.15$ & $\begin{array}{l}\text { Materi 1: } \\
\text { Pandangan umum mengenai fenomena } \\
\text { Sekolah }\end{array}$ & $\begin{array}{l}\text { Dr. Ida Bagus Kade } \\
\text { Gunayasa, M.Hum }\end{array}$ \\
\hline 6 & $10.15-10.30$ & $\begin{array}{l}\text { Materi 2: Prinsip-prinsip pengembangan } \\
\text { literasi baca dan numerasi di Sekolah }\end{array}$ & $\begin{array}{l}\text { Ketut Sri Kusuma } \\
\text { Wardani, M.Pd }\end{array}$ \\
\hline 7 & $10.30-10.45$ & $\begin{array}{l}\text { Materi 3: Strategi pengembangan literasi } \\
\text { baca dan numerasi di Sekolah }\end{array}$ & $\begin{array}{l}\text { Moh.Irawan Zain, } \\
\text { S.Pd., M.Pd }\end{array}$ \\
\hline 8 & $10.45-11.15$ & $\begin{array}{l}\text { Materi 4: Pengembangan Media Pop Up Box } \\
\text { dan Praktik Penggunaan Media Pop Up Box }\end{array}$ & $\begin{array}{l}\text { Baiq Wini Audia } \\
\text { Damayanti }\end{array}$ \\
\hline 9 & $11.15-11.45$ & $\begin{array}{l}\text { Diskusi } \\
\text { MC (Fitri Puji Astria, } \\
\text { M.Pd) }\end{array}$ \\
\hline 10 & $12.45-12.00$ & $\begin{array}{l}\text { Penutupan } \\
\text { MC (Fitri Puji Astria, } \\
\text { M.Pd) }\end{array}$ \\
\hline
\end{tabular}

Kegiatan dilaksanakan secara offline (tatap muka), sesuai dengan permintaan dari pihak ketua PGRI Kabupaten Lombok Tengah. Protokol kesehatan tetap dijaga, dimana tempat pelaksanaan sudah menyediakan handsainitizer di ruangan, serta pengaturan bangku yang berjarak. Adapun jumlah peserta yang hadir dalam kegiatan ini adalah 38 guru yang berasal dari Guru Sekolah Dasar se-Kecamatan Praya Lombok Tengah.

\section{$2.4 \quad$ Tahap Evaluasi}

Untuk mengukur keberhasilan kegiatan, tim pengabdian menggunakan angket respon peserta. Angket respon peserta diharapkan dapat menjangkau informasi terkait kebermanfaatan kegiatan yang dilaksanakan bagi guru Sekolah Dasar se-Kecamatan Praya Lombok Tengah sebagai peserta. Instrumen angket respon juga dapat menjadi bahan refleksi bagi tim pelaksana dalam menyelenggarakan kegiatan pengabdian kepada masyarakat selanjutnya

\section{HASIL DAN PEMBAHASAN}

\subsection{Pelaksanaan Kegiatan}

Kegiatan pengabdian kepada masyarakat ini dilakukan di Gedung PGRI Lombok Tengah. Rincian kegiatan penyuluhan tentang pengembangan literasi baca dan numerasi melalui media pop up box di Sekolah Dasar Se-Kecamatan Praya Lombok Tengah adalah sebagai berikut: 
Kegiatan pengabdian ini diikuti oleh 38 Guru Sekolah Dasar Se-Kecamatan Praya Lombok Tengah. Kegiatan dilaksanakan tepat waktu yaitu pukul 09.00 Wita. Kegiatan diawali dengan sambutan yang diberikan oleh ketua tim pengabdian dan Ketua PGRI Kabupaten Lombok Tengah.

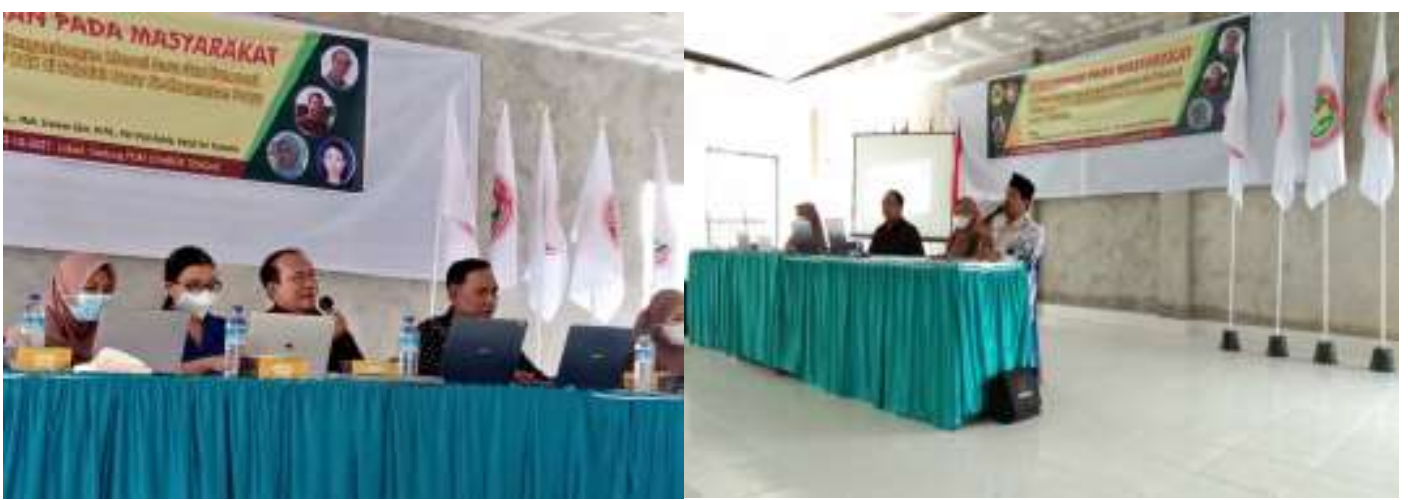

Gambar 4. Sambutan oleh Ketua Tim Pengabdian dan Ketua PGRI Kabupaten Lombok Tengah

Kegiatan selanjutnya adalah penyampaian materi oleh masing-masing narasumber. Materi pertama tentang pandangan umum mengenai fenomena budaya literasi dalam dunia Pendidikan di Sekolah oleh Dr. Ida Bagus Kade Gunayasa, M.Hum. Materi kedua tentang prinsipprinsip pengembangan literasi baca dan numerasi di Sekolah oleh Ketut Sri Kusuma Wardani, S.Pd., M.Pd. Hal ini penting karena dengan budaya literasi dimaksudkan untuk melakukan kebiasaan berpikir yang diikuti proses membaca menulis. Melalui penguatan budaya baca, mutu pendidikan dapat ditingkatkan sehingga dapat meningkatkan kualitas sumber daya manusia. Melalui penguatan budaya baca pulalah pendidikan seumur hidup (long life education) dapat diwujudkan.
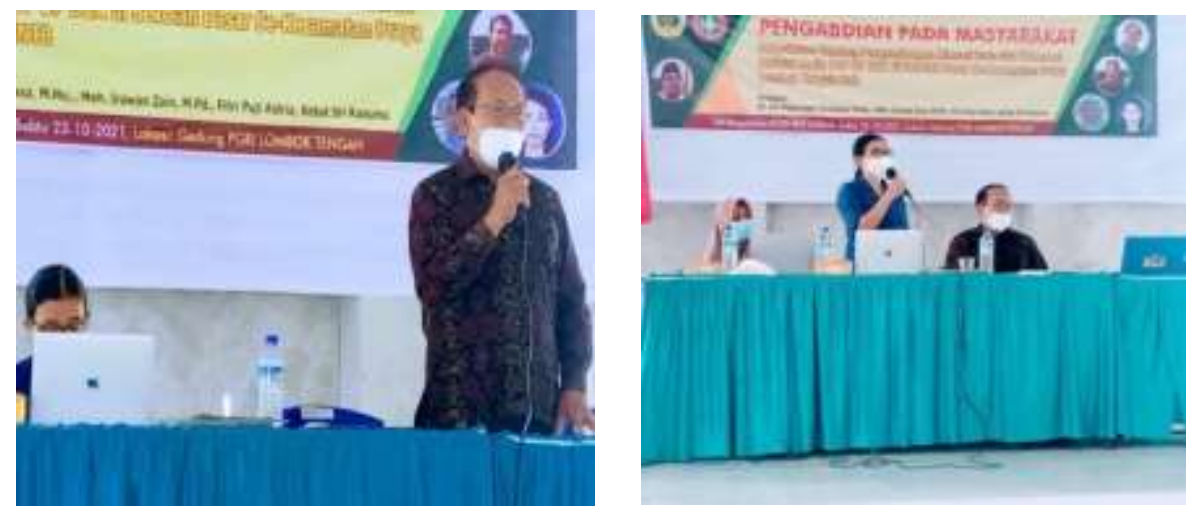

Gambar 5. Penyampaian Materi oleh Pemateri 1 (Dr. Ida Bagus Kade Gunayasa, M.Hum) dan Pemateri 2 (Ketut Sri Kusuma Wardani, S.Pd., M.Pd)

Kegiatan berikutnya, dilanjutkan penyampaian meteri ketiga oleh pemateri ketiga tentang strategi pengembangan literasi baca dan numerasi di Sekolah oleh Moh.Irawan Zain, S.Pd., M.Pd. Kemudian dilanjutkan Kembali oleh pemateri keempat tentang pengembangan media pop up box dan praktik penggunaan media pop up box oleh Baiq Wini Audia Damayanti. Menurut Aisyah (2018), media visual pop up box, sebagai bagian media pembelajaran berbasis visual memiliki kelebihan yaitu mempermudah dan mempercepat pemahaman siswa terhadap pesan yang disajikan, dapat dilengkapi dengan warna-warna sehingga lebih menarik perhatian siswa. 


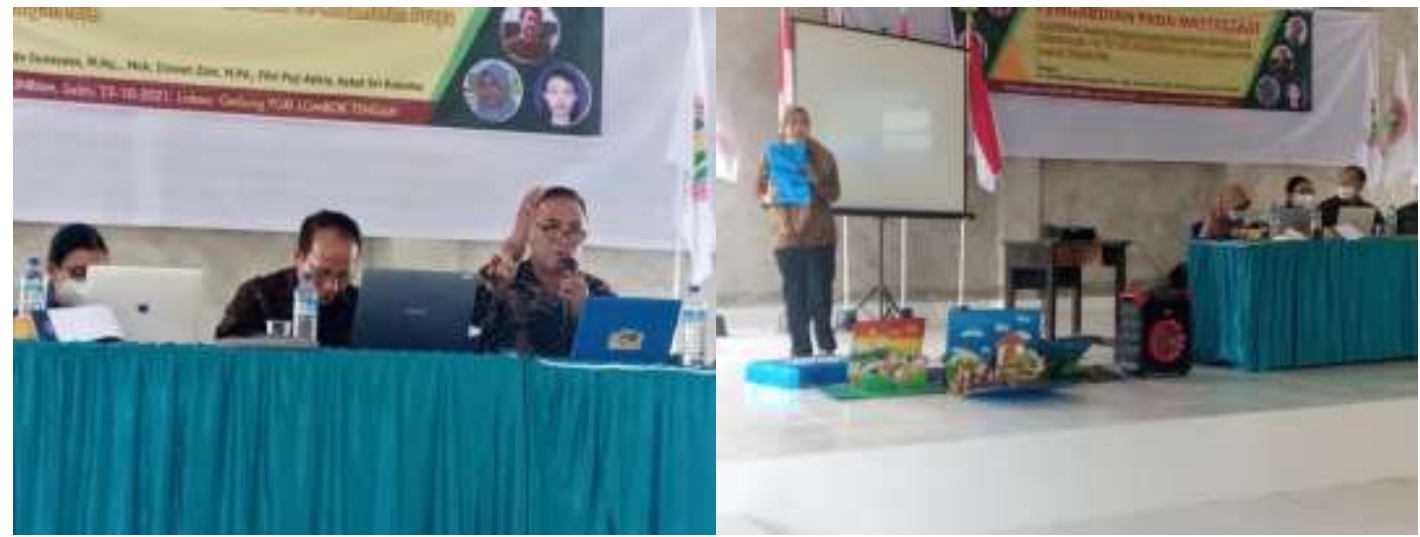

Gambar 6. Penyampaian Materi oleh Pemateri 3 (Moh.Irawan Zain, S.Pd., M.Pd) dan Pemateri 4 (Baiq Wini Audia Damayanti)

Kegiatan selanjutnya adalah diskusi tanya jawab yang dilakukan untuk memperkuat pemahaman peserta terhadap pengembangan literasi baca dan numerasi melalui media pop up box. Kegiatan diskusi dilaksanakan dengan dua sesi dengan masing-masing sesi diberikan waktu untuk dua orang penanya dari peserta kegiatan penyuluhan.

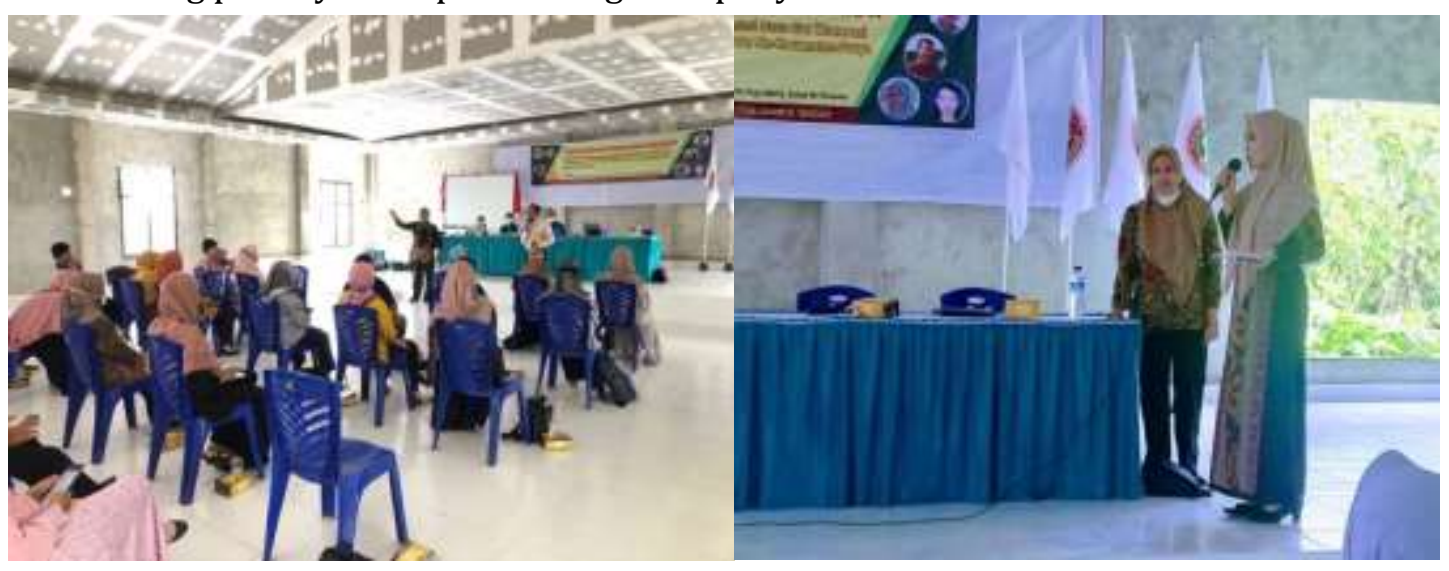

Gambar 7. Kegiatan diskusi antara narasumber dengan peserta

\subsection{Evaluasi Kegiatan}

Untuk mengukur keberhasilan kegiatan, tim pengabdian menggunakan angket respon peserta. Adapun hasil pengisian angket tersebut dipaparkan sebagai berikut:

Ketepatan waktu pelaksanaan penyluhan aijuntom
Narasumber menguasai materi penyuluhan 39 jewitan

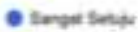
- senda

e Kung teho.

- Tine lints.

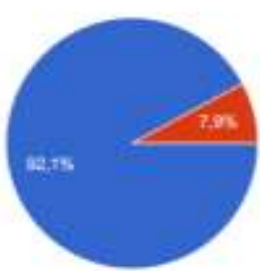

- Sargal Setuéu

- Sethiv

Kurarg Sowij - Tdear Sutiu 
Narasumber memberikan kesempatan tarya-jawab 3e jewaben

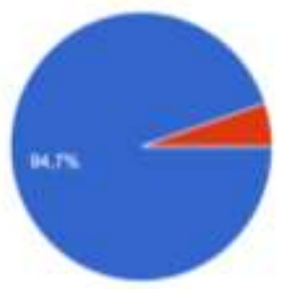

Narasumber mervajikan materimy dengan jalas dan berurutan 39 jematan
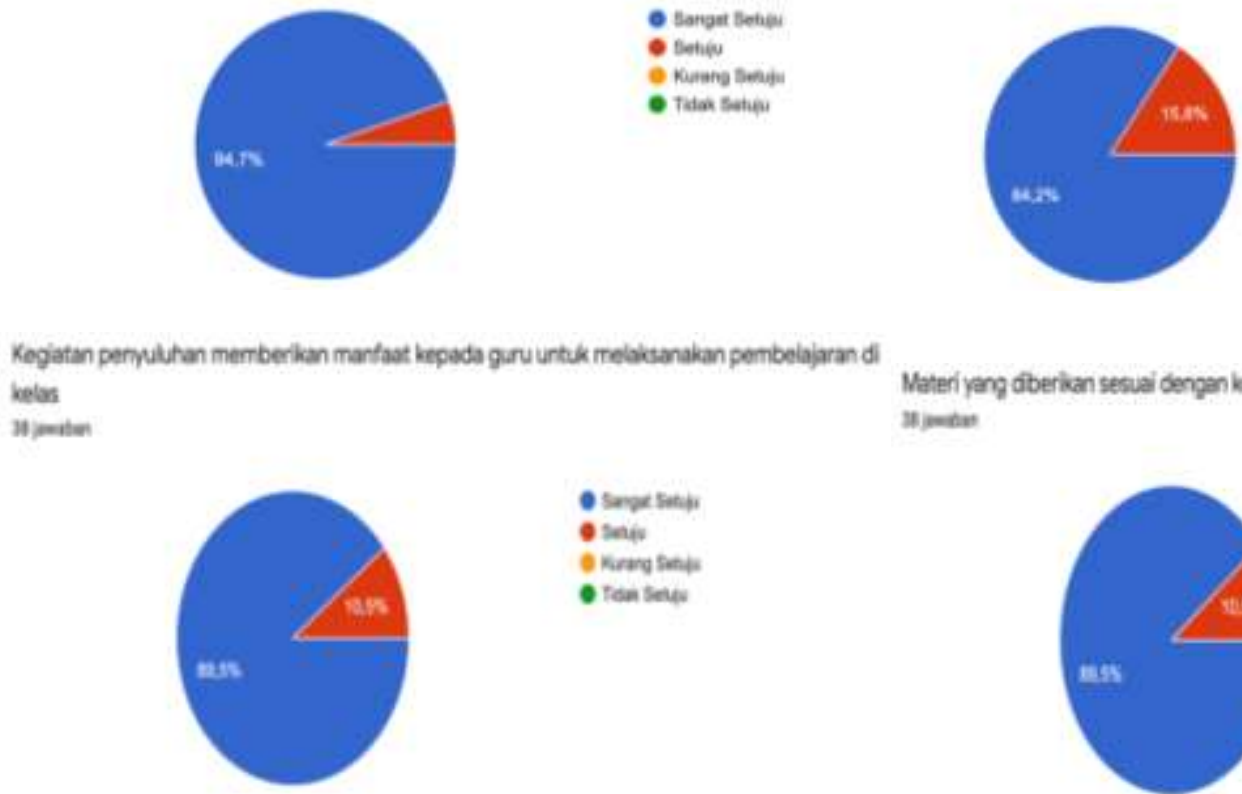

e sarue Saly

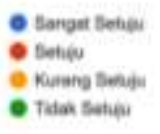

Materi yang dberkan sesuai dengan kebutuhan gunu di Sekclah ujens

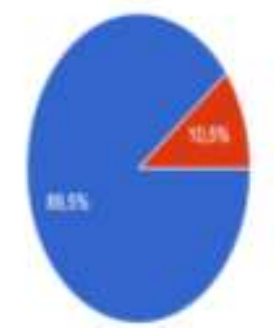

- Sangiseta: C sani.

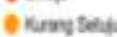
- Tas lime.

Materi permulhan dapat diterima dan diterapkan dengan mudah sojumatien
Fasilitas dan sarana pendukung kegiatan penyuluhan sudah mernadai 38 jamiban
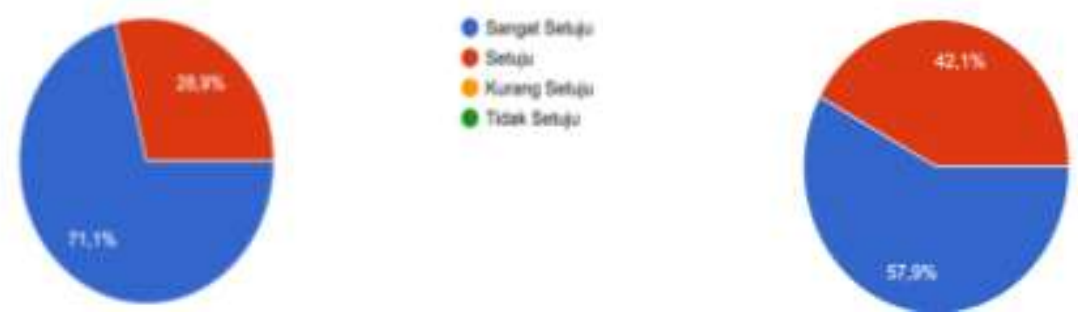

- Sangar Seripu - Setuy

- Kunng Setupu - Tedar Sahija

Gambar 8. Rekapitulasi hasil angket respon peserta

Pada gambar 8, telah dipaparkan rekapitulasi hasil angket respon peserta. Pada aspek ketepatan waktu, 71,1\% peserta menjawab sangat setuju dan 28,9\% peserta menjawab setuju. Hal ini menujukkan bahwa kegiatan berjalan sesuai dengan rundown acara yang disusun oleh tim pengabdian. Pada aspek narasumber menguasai materi penyuluhan, 92,1\% peserta menjawab sangat setuju dan 7,9\% lainya menjawab setuju. Hal ini menunjukkan bahwa narasumber yang menyampaikan materi penyuluhan sudah berhasil memaparkan meterinya dengan baik. Pada aspek narasumber memberikan waktu tanya-jawab, 94,7\% peserta menjawab sangat setuju dan 5,7\% peserta menjawab setuju. Hal ini menunjukkan bahwa proses kegiatan diskusi berlangsung dengan baik dan peserta sangat antusias. Pada aspek narasumber menyampaikan materi dengan jelas dan berurutan, 84,2\% peserta menjawab sangat setuju dan 15,8\% peserta menjawab setuju. Hal ini menunjukkan materi yang disampaikan oleh narasumber sangat sistematis dan sesuai dengan urutan materi pada rundown acara.

Pada aspek kegiatan penyuluhan memberikan manfaat kepada guru untuk melaksanakan pembelajaran di kelas, 89,5\% menjawab sangat setuju dan 10,5\% menjawab setuju. Hal ini menunjukkan bahwa kegiatan penyuluhan sangat bermanfaat bagi peserta untuk mengembangkan potensinya dalam melaksanakan pembelajaran di kelas. Pada aspek materi yang diberikan sesuai dengan kebutuhan guru di sekolah 89,5\% menjawab sangat setuju dan 10,5\% menjawab setuju. Hal ini menunjukkan bahwa materi yang diberikan sesuai dengan kebutuhan guru di sekolah. Pada aspek materi penyuluhan dapat diterima dan diterapkan dengan mudah, 71,1\% peserta menjawab sangat setuju dan 28,9\% peserta menjawab setuju. Hal ini menujukkan bahwa materi yang disampaikan oleh narasumber dapat diterima dan diterapkan oleh peserta. 
Pada aspek fasilitas dan sarana pendukung kegiatan penyuluhan sudah memadai, 57,9\% menjawab sangat setuju dan 42,1 menjawab setuju. Hal ini menunjukkan bahwa fasilitas dan sarana pendukung kegiatan penyuluhan sudah memadai untuk menunjang kegiatan penyuluhan. Dengan demikian, dapat disumpulkan bahwa respon peserta terhadap kegiatan penyuluhan tentang pengembangan literasi baca dan numerasi melalui media pop up box yang dilaksanakan untuk guru sekolah dasar se-Kecamatan Praya Lombok Tengah sudah terlaksana dengan sangat baik.

\section{KESIMPULAN}

Berdasarkan hasil kegiatan pengabdian kepada masyarakat dengan judul "Penyuluhan Tentang Pengembangan Literasi Baca dan Numerasi Melalui Media Pop Up Box di Sekolah Dasar Se-Kecamatan Praya Lombok Tengah" yang telah dilaksanakan maka dapat disimpulan pelaksanaan kegiatan penyuluhan ini berjalan lancar sesuai dengan perencanaan jadwal yang telah ditetapkan. Tidak terdapat hambatan dan masalah selama kegiatan penyuluhan ini, peserta dapat hadir melaksanakan setiap rangkaian kegiatan yang telah disusun oleh tim pengabdian. Seluruh rangkaian kegiatan mulai dari tahap persiapan, tahap menyediakan alat dan bahan, tahap pelaksanaan dan tahap evaluasi kegiatan berjalan dengan baik dan lancar.

Untuk mengukur keberhasilan kegiatan, tim pengabdian menggunakan angket respon peserta dengan hasil sebagai berikut: pada aspek ketepatan waktu, 71,1\% peserta menjawab sangat setuju dan $28,9 \%$ peserta menjawab setuju. Hal ini menujukkan bahwa kegiatan berjalan sesuai dengan rundown acara yang disusun oleh tim pengabdian. Pada aspek narasumber menguasai materi penyuluhan, 92,1\% peserta menjawab sangat setuju dan $7,9 \%$ lainya menjawab setuju. Hal ini menunjukkan bahwa narasumber yang menyampaikan materi penyuluhan sudah berhasil memaparkan meterinya dengan baik. Pada aspek narasumber memberikan waktu tanyajawab, 94,7\% peserta menjawab sangat setuju dan 5,7\% peserta menjawab setuju. Hal ini menunjukkan bahwa proses kegiatan diskusi berlangsung dengan baik dan peserta sangat antusias. Pada aspek narasumber menyampaikan materi dengan jelas dan berurutan, 84,2\% peserta menjawab sangat setuju dan $15,8 \%$ peserta menjawab setuju. Hal ini menunjukkan materi yang disampaikan oleh narasumber sangat sistematis dan sesuai dengan urutan materi pada rundown acara.

Pada aspek kegiatan penyuluhan memberikan manfaat kepada guru untuk melaksanakan pembelajaran di kelas, $89,5 \%$ menjawab sangat setuju dan $10,5 \%$ menjawab setuju. Hal ini menunjukkan bahwa kegiatan penyuluhan sangat bermanfaat bagi peserta untuk mengembangkan potensinya dalam melaksanakan pembelajaran di kelas. Pada aspek materi yang diberikan sesuai dengan kebutuhan guru di sekolah 89,5\% menjawab sangat setuju dan 10,5\% menjawab setuju. Hal ini menunjukkan bahwa materi yang diberikan sesuai dengan kebutuhan guru di sekolah. Pada aspek materi penyuluhan dapat diterima dan diterapkan dengan mudah, $71,1 \%$ peserta menjawab sangat setuju dan $28,9 \%$ peserta menjawab setuju. Hal ini menujukkan bahwa materi yang disampaikan oleh narasumber dapat diterima dan diterapkan oleh peserta. Pada aspek fasilitas dan sarana pendukung kegiatan penyuluhan sudah memadai, 57,9\% menjawab sangat setuju dan 42,1 menjawab setuju. Hal ini menunjukkan bahwa fasilitas dan sarana pendukung kegiatan penyuluhan sudah memadai untuk menunjang kegiatan penyuluhan. Dengan demikian, dapat disumpulkan bahwa respon peserta terhadap kegiatan penyuluhan tentang pengembangan literasi baca dan numerasi melalui media pop up box yang dilaksanakan untuk guru sekolah dasar se-Kecamatan Praya Lombok Tengah sudah terlaksana dengan sangat baik.

Terdapat beberapa hal yang dapat direkomendasikan dan dapat ditindaklanjuti dari hasil kegiatan penyuluhan ini, sebagai berikut:

1) Diperlukan kesadaran pendidik akan pentingnya penggunaan media pembelajaran sebagai upaya mengembangkan literasi baca dan numerasi siswa di sekolah dasar. 
2) Adanya kerjasama yang berkelanjutan antara guru sekolah dasar se-kecamatan Praya Lombok Tengah dengan Program Studi Pendidikan Guru Sekolah Dasar Universitas Mataram untuk meningkatkan keterampilan guru dalam mengembangkan media pembelajaran inovatif.

\section{DAFTAR PUSTAKA}

Aisyah, A. M. (2018). “Pengembangan Media Pop Up Box Pada Mata Pelajaran Matematika Untuk Siswa Kelas III Sekolah Dasar" (Doctoral dissertation, University of Muhammadiyah Malang).

Aprinawati, I. (2017). "Penggunaan Media Gambar Seri Untuk Meningkatkan Kemampuan Berbicara Anak Usia Dini”. Jurnal Obsesi: Jurnal Pendidikan Anak Usia Dini, 1(1), 72-80.

Arsyad, Azhar. (2016). Media Pembelajaran. Jakarta: Raja Grafindo Persada.

Cahyadi, Ani. (2019). Pengembangan Media dan Sumber Belajar Teori dan Prosedur. Serang : Laksita Indonesia.

Kementerian Pendidikan dan Kebudayaan. (2014). Buku Guru Bahasa Indonesia Ekspresi Diridan Akademik Kelas X. Kementerian Pendidikan dan Kebudayaan: Jakarta.

Khair, B. N., Astria, F. P., Wardani, K. S. K., Nurwahidah, N., \& Sriwarthini, N. N. (2021). Pengembangan LKPD Literasi Sains Berbasis Lesson Study for Learning Community (LSLC). Jurnal Pijar Mipa, 16(1), 136-141.

Kosasih, E. 2015. Strategi Belajar dan Pembelajaran Implementasi Kurikulum 2013. Yrama Widya: Bandung.

Kurniawan, Endang dan PPPPTK Bahasa. (2015). Materi Pelatihan Guru Implementasi Kurikulum 2013. Badan Pengembangan Sumber Daya Manusia Pendidikan dan Kebudayaan dan Penjaminan Mutu Pendidikan.

Mahsun. (2014). Teks dalam Pembelajaran Bahasa Indonesia Kurikulum 2013. Jakarta: PT Raja Grafindo Persada.

Martani, F. R. R. W. (2020). Pengembangan Media Exploding Box Pada Materi Ciri-Ciri Dan Klasifikasi Makhluk Hidup Kelas VII SMP. Skripsi.

Maulida, K. T. (2018). "Pengaruh penggunaan media gambar seri terhadap keterampilan menulis karangan sederhana pada pelajaran bahasa Indonesia siswa kelas III MI AtThohiriyyah Kecamatan Pedurungan Kota Semarang tahun pelajaran 2017/2018“ (Doctoral dissertation, UIN Walisongo Semarang).

Ni'mah, N. I. (2014). "Efektifitas Penggunaan Media Pop Up Dalam Pengajaran Keterampilan Berbicara Bahasa Prancis Siswa Kelas XI SMA Negeri 1 Mertoyudan Magelang". Skripsi.FBS-UNY.

Paringan, 0. (2018). "Pengembangan Media Pembelajaran Exploding Box Pop Up 3D Pada Pembelajaran Tematik Tema 5 Subtema 1 Di Kelas IV Sekolah Dasar" (Doctoral dissertation, University of Muhammadiyah Malang).

Safri, M., Sari, S. A., \& Marlina, M. (2017). “Pengembangan Media Belajar Pop-Up Book pada Materi Minyak Bumi. Jurnal Pendidikan Sains Indonesia". Indonesian Journal of Science Education, 5(1), 107-113.

Salinan Peraturan Menteri Pendidikan dan Kebudayaan Republik Indonesia Nomor 24 Tahun 2016 tentang Kompetensi Inti dan Kompetensi Dasar Pelajaran Kurikulum 2013 pada Pendidikan Dasar dan Menengah. 
Salinan Peraturan Menteri Pendidikan dan Kebudayaan Republik Indonesia Nomor 23 Tahun 2015 tentang Penumbuhan Budi Pekerti.

Wahyuni,R. (2019). "Pengembangan Media Pembelajaran Gambar Berseri Berbasis Pop-Up Book Untuk Meningkatkan Keterampilan Menulis Narasi Bahasa Indonesia Kelas IV DiSd/Mi" (Doctoral dissertation, UIN Raden Intan Lampung).

Wardani, K. S. K., Sadia, I. W., \& Suastra, I. W. (2016). Pengembangan perangkat pembelajaran IPA terpadu dengan setting inquiry laboratorium bermuatan content local genius untuk meningkatkan pemahaman konsep dan keterampilan proses sains siswa SMP. In Prosiding Seminar Nasional MIPA. 